УДК 624.131

DOI: 10.17277/voprosy.2016.03.pp.031-037

\title{
EXPERIMENTAL STUDIES OF THE STABILITY OF REINFORSED SAND SLOPES
}

\author{
V. M. Antonov, M. V. Antonov, \\ O. V. Evdokimtsev, V. V. Ledenev \\ Tambov State Technical University, Tambov, Russia \\ Reviewed by Doctor of Technical Sciences, \\ Professor P. V. Monastyrev
}

Keywords: breaking load; cyclic loading; deformation; reinforcement; slope.

\begin{abstract}
The results of experimental studies of reinforced sandy slope stability under the action of vertical surcharge are presented in the article. There have been made a few series of experiments in which the depth of the reinforcing element, as well as the parameters of reloading - cyclical (5, 10 and 20 load cycles) and static one - were varied. The case of the presence of the weak soil interlayer situated at different depths within the slope is discussed.

The dependences of the influencing parameters on the displacements and limit pressures under the pilot stamp foundationbed have been obtained. It is shown that fabric-reinforced slope can bear vertical load almost two times greater than a non-reinforced one, with smaller deformations. Absolute values of the breaking load after cycling are greater than those at static loads. It is found that the use of reinforcement eliminates the possibility of the landslide collapse of the slope and the location of the weak soil interlayer at a depth greater than the diameter of the model has almost no effect on the slope bearing capacity and makes the reinforcement in this area ineffective.
\end{abstract}

Slopes are the most common engineering structures. Their operating conditions tend to be unfavorable and unpredictable. Possible geological processes and phenomena on territories with slopes, causes and patterns

Антонов Василий Михайлович - кандидат технических наук, доцент кафедры «Конструкции зданий и сооружений»; e-mail: kzis@nnn.tstu.ru; Антонов Михаил Васильевич аспирант кафедры «Конструкции зданий и сооружений»; Евдокимцев Олег Владимирович кандидат технических наук, доцент кафедры «Конструкции зданий и сооружений»; Леденев Виктор Васильевич - доктор технических наук, профессор кафедры «Конструкции зданий и сооружений», ТамбГТУ, г. Тамбов, Россия. 
of positive stability are described in detail in [1]. One of the most effective ways to increase the stability of slopes is the reinforcement of soils with different materials [2]. Several methods of calculating unreinforced [3, 4] and reinforced $[5,6]$ slopes are known. For the first type, sufficiently large experimental data have been verified, while for the second one the experimental data are scarce. This is due to the complexity of technical execution of experiments and the influence of a number of factors (characteristics: slope, soil reinforcement and loadings). Rheological processes occurring in the soil, reinforcing elements and their contact with the ground are important. The presence of the slope near the foundation has a significant impact on its bearing capacity and displacement. Theoretical and experimental research in this direction is not sufficient.

In this regard, we have tasked to conduct experimental studies of the interaction of shallow foundation with reinforced soil slope. The purpose of the research is to determine the optimum design solution, calculate design life, admissible displacements and impacts.

The experiments were performed in the Laboratory of Soil Mechanics of TSTU (Tambov State Technical University, Tambov). Reinforced foundations have been studied for over 15 years. Some details about the method of testing and the results were described in $[7,8]$.

The slope was formed from small homogeneous layers of compacted to $1.51 \mathrm{~g} / \mathrm{cm}^{3}$, little wet $\omega=0.08$ sand (see Fig. 1). As a reinforcement element we used reinforcement mesh from metal-crystal rods with a diameter $d_{s}=3 \mathrm{~mm}$, the bar spacing was $25 \mathrm{~mm}$, the plan dimension was $350 \times 125 \mathrm{~mm}$.

The influencing parameters included: the slope height; the slope angle to the horizon (600); diameter of rigid steel punch $D_{s t}=150 \mathrm{~mm}$; the distance to the reinforcing element $h_{s}$; the relative distance $\bar{h}=h_{s} / D_{s t}$; the diameter of mesh rods $d_{s}$; the bar spacing $a_{s}$; mesh size; the current and breaking value of the load $F, F_{u}$; the corresponding pressure $p$ and $p_{u}$; load level $\bar{F}=F / F_{u}$ or $\bar{p}=p / p_{u}$; the punch subsidence $s$, the horizontal displacement $u$, tilt $i$; the limit values of displacements (before fracture) $s_{u}, u_{u}, i_{u}$; the number of loading cycles $n_{c}$; the

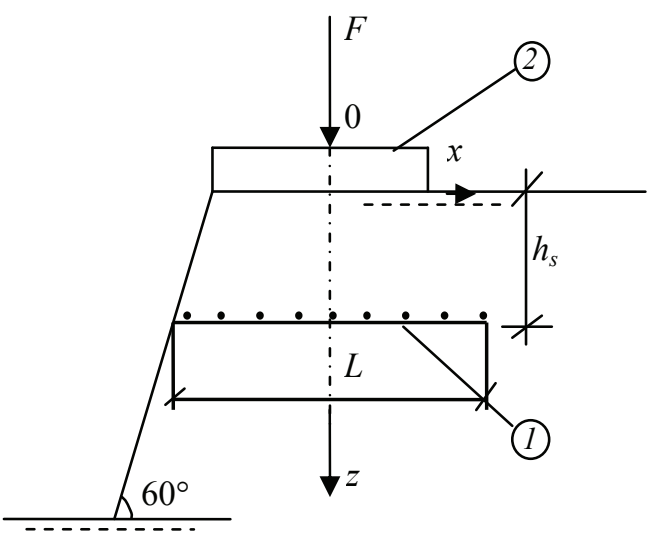

Fig. 1. Layout of the reinforcement element (1) and the foundation model (2) $(E=5 \mathrm{mPa} ; \varphi=280 ; c=3 \mathrm{kPa}$; $\rho=1.52$ г/см) cycle stress ratio $\rho_{c}=F_{\text {min }} / F_{\text {max }}$ or $p_{\min } / p_{\max }$.

Other important parameters included the distance from the brink of the slope to the axis of the foundation $L_{s t}$, the relative value of $\bar{L}_{s t}=L_{s t} / D_{s t}$. At a certain value of $\bar{L}_{s t} \geq \hat{L}_{s t}$ the slope influence on the bearing capacity of the foundation and the punch displacement is insignificant and can be ignored; if under $\bar{L}_{s t}<\hat{L}_{s t}$ there is additional punch displacement, their direction is changed and load-carrying capacity is reduced. 
Table 1

The influence of the distance to the reinforcing element on slope stability

\begin{tabular}{c|c|c|c|c}
\hline $\bar{h}$ & $P, \mathrm{kPa}$ & $s, \mathrm{~cm}$ & $u, \mathrm{~cm}$ & $i$ \\
\hline 0.2 & 55.03 & 1.41 & 0.18 & 0.014 \\
0.4 & 70.05 & 1.63 & 0.25 & 0.015 \\
0.6 & 36.7 & 1.88 & 0.62 & 0.003 \\
\hline
\end{tabular}

Several series of experiments with three replications were conducted. Loading stages were $0.1 F_{u}$. Conditional stabilization of deformation was $0.1 \mathrm{~mm}$ for $30 \mathrm{~min}$ of observation. The efficacy of reinforcement was assessed by $p_{u}$ value and speed of displacements $\dot{s}, \dot{u}, \dot{i}$. The values of subsidence, horizontal displacements and tilt were calculated in the last stage of loading, before the destruction.

In the first series of experiments (Table 1) we changed the depth of the reinforcing element $\left(\bar{h}_{s}=0.2,0.4,0.6\right)$. Step-by-step loading was applied to cause fracture (Table 1). In the experiments without reinforcement $p_{u}=33.6 \mathrm{kPa}$.

Reinforcement enabled to increase the carrying capacity of the foundation by $30-100 \%$ and reduce the deformability by $20-40 \%$. The fracture under mesh embedment $\bar{h}=0.6$ occurred in the form of ground punching, which led to the formation of cracks at both horizontal and downhill surfaces of the slope, while under $\bar{h}=0.2$ and 0.4 the fracture was in the form of a landslide collapse of soil.

Table 2

The influence of the level of cyclic loading on slope stability

\begin{tabular}{c|c|c|c}
\hline $\bar{h}=h_{s} / D$ & $\bar{F}$ & $P, \mathrm{kPa}$ & $s, \mathrm{~cm}$ \\
\hline \multirow{3}{*}{0.2} & 0.6 & 66.03 & 1.24 \\
& 0.7 & 73.38 & 1.35 \\
& 0.8 & 68.45 & 1.42 \\
& 0.9 & 61.14 & 1.15 \\
\hline \multirow{3}{*}{0.4} & 0.6 & 70.91 & 1.1 \\
& 0.7 & 73.38 & 1.31 \\
& 0.8 & 70.91 & 1.49 \\
& 0.9 & 40.36 & 1.12 \\
\hline \multirow{3}{*}{0.6} & 0.6 & 45.24 & 2.21 \\
& 0.7 & 47.23 & 2.34 \\
& 0.8 & & 2.12 \\
\hline
\end{tabular}


In the second series we applied cyclic load $\rho_{c}=0.6,0.7,0.8,0.9$. The tests were carried as follows: the load was increased to the desired level, 5 cycles were performed, and after $10 \mathrm{~min}$ another 10 cycles were performed, and 10 min later another 20 cycles were performed. Hereinafter, static load was applied to cause foundation fracture and punch turnover.

The results of the second series (Tables 2, 3 and 4) confirmed that the reinforcement of the lower zone of the slope at the depth $0.6 D_{s t}$ is inefficient. The absolute values of the breaking load after cycling were higher than those after the static cycling; apparently, this is due to the fact that the cyclic impacts cause rearrangement of particles in a tighter pack. The highest values were obtained under cyclic load, which equaled to $0.7-0.8$ of breaking load. Under $\bar{F}=0.9$ the fracture occurred at the stage of application of cyclic loads.

Table 3

\section{The influence of the distance from the bottom of the stamp to reinforcement and to the weak layer on strength and stability of the slope}

\begin{tabular}{|c|c|c|c|c|c|}
\hline $\begin{array}{c}\text { Distance to } \\
\text { the weak layer } \\
h, \mathrm{~cm}\end{array}$ & $\begin{array}{l}\text { Distance to the } \\
\text { reinforcement } \\
h_{s}, \mathrm{~cm}\end{array}$ & $\begin{array}{c}\text { Pressure } \\
\text { limits } P_{u}, \mathrm{kPa}\end{array}$ & $\begin{array}{c}\text { Subsidence } \\
s_{u}, \mathrm{~cm}\end{array}$ & Tilt $i_{u}$ & $\begin{array}{c}\text { Horizontal } \\
\text { displacement } \\
u_{u}, \mathrm{~cm}\end{array}$ \\
\hline $\begin{array}{l}\text { Without } \\
\text { interlayer }\end{array}$ & - & 33.6 & 2.1 & 0.03 & 0.39 \\
\hline 4 & - & 26.4 & 2.80 & 0.050 & 0.50 \\
\hline \multirow{3}{*}{6} & - & 28.8 & 2.40 & 0.043 & 0.45 \\
\hline & 2 & 36.0 & 1.88 & 0,020 & 0.40 \\
\hline & 4 & 39.6 & 1.60 & 0.025 & 0.35 \\
\hline \multirow{4}{*}{8} & - & 28.4 & 2.2 & 0.038 & 0.48 \\
\hline & 2 & 34.8 & 2.00 & 0.032 & 0.45 \\
\hline & 4 & 43.2 & 1.75 & \multirow{2}{*}{0.020} & 0.40 \\
\hline & 6 & 38.4 & 2.30 & & 0.56 \\
\hline \multirow{5}{*}{10} & - & 33.6 & 2.20 & 0,030 & 0.35 \\
\hline & 2 & 42.0 & 1.45 & 0.020 & 0.28 \\
\hline & 4 & 45.6 & 1.50 & 0.015 & 0.15 \\
\hline & 6 & 38.4 & 1.95 & 0.035 & 0.26 \\
\hline & 8 & 34.8 & 2.30 & 0.045 & 0.30 \\
\hline \multirow{6}{*}{12} & - & 33.6 & 2.20 & 0.024 & 0.25 \\
\hline & 2 & 38.4 & 2.05 & 0.020 & \multirow{2}{*}{0.15} \\
\hline & 4 & 46.0 & 1.66 & 0.015 & \\
\hline & 6 & 42.0 & 1.51 & 0.012 & 0.20 \\
\hline & 8 & 39.6 & 2.10 & 0.038 & 0.35 \\
\hline & 10 & 34.8 & 2.40 & 0.043 & 0.50 \\
\hline
\end{tabular}


Table 4

Pressure and deformation limits under cyclic loading

\begin{tabular}{|c|c|c|c|c|c|c|}
\hline \multirow{2}{*}{$\begin{array}{c}\text { Distance } \\
\text { to the weak } \\
\text { layer } h, \mathrm{~cm}\end{array}$} & \multirow{2}{*}{$\begin{array}{c}\text { Distance to the } \\
\text { reinforcement } \\
h_{s}, \mathrm{~cm}\end{array}$} & \multirow{2}{*}{$\bar{F}$} & \multirow{2}{*}{$\begin{array}{c}\text { Pressure } \\
\text { limits } \\
P_{u}, \mathrm{kPa}\end{array}$} & \multicolumn{2}{|c|}{$\begin{array}{c}\text { subsidence increment } \\
\qquad \Delta s, \mathrm{~cm}\end{array}$} & \multirow{2}{*}{$\begin{array}{c}\text { Subsidence } \\
s_{u}, \mathrm{~cm}\end{array}$} \\
\hline & & & & $\begin{array}{l}1 \text { stage - } \\
10 \text { cycles }\end{array}$ & $\begin{array}{l}2 \text { stage }- \\
20 \text { cycles }\end{array}$ & \\
\hline 1 & 2 & 3 & 4 & 5 & 6 & 7 \\
\hline \multirow{4}{*}{4} & \multirow{8}{*}{2} & 0.6 & 45.1 & 0.33 & 0.15 & 0.94 \\
\hline & & 0.7 & 46.1 & 0.48 & 0.17 & 1.25 \\
\hline & & 0.8 & 47.0 & 0.36 & 0.30 & 1.08 \\
\hline & & 0.9 & 48.6 & 0.39 & 0.23 & 1.12 \\
\hline \multirow{8}{*}{6} & & 0.6 & 44.2 & 0.31 & 0.17 & 0.87 \\
\hline & & 0.7 & 40.5 & 0.30 & 0.35 & 0.97 \\
\hline & & 0.8 & 39.8 & 0.36 & 0.29 & 1.12 \\
\hline & & 0.9 & 40 & 0.4 & 0.26 & 1.18 \\
\hline & \multirow{4}{*}{4} & 0.6 & 43.0 & 0.23 & 0.20 & 0.69 \\
\hline & & 0.7 & 380 & 0.20 & 0.16 & 0.75 \\
\hline & & 0.8 & & 0.22 & 0.21 & 0.84 \\
\hline & & 0.9 & 37.0 & 0.29 & 0.25 & 0.86 \\
\hline \multirow{12}{*}{8} & \multirow{4}{*}{2} & 0.6 & 350 & 0.21 & 0.18 & 0.89 \\
\hline & & 0.7 & 53.0 & 0.29 & 0.24 & 0.92 \\
\hline & & 0.8 & 34.8 & 0.31 & 0.30 & 1.20 \\
\hline & & 0.9 & 34.0 & 0.36 & 0.22 & 0.99 \\
\hline & \multirow{4}{*}{4} & 0.6 & 42.5 & 0.29 & 0.25 & 0.79 \\
\hline & & 0.7 & 45.0 & 0.31 & 0.18 & 0.85 \\
\hline & & 0.8 & 42.2 & 0.35 & 0.25 & 0.89 \\
\hline & & 0.9 & 43.2 & 0.40 & 0.34 & 1.02 \\
\hline & \multirow{4}{*}{6} & 0.6 & 32 & 0.29 & 0.27 & 0.95 \\
\hline & & 0.7 & 34 & 0.44 & 0.25 & 0.99 \\
\hline & & 0.8 & 35 & 0.40 & 0.29 & 1.14 \\
\hline & & 0.9 & נכ & 0.48 & 0.33 & $1.8^{*}$ \\
\hline \multirow{4}{*}{10} & \multirow{4}{*}{2} & 0.6 & 40.20 & 0.28 & 0.28 & 0.810 \\
\hline & & 0.7 & 40.26 & 0.34 & 0.32 & 0.830 \\
\hline & & 0.8 & 40.80 & 0.33 & 0.28 & $1.65^{*}$ \\
\hline & & 0.9 & 41.20 & 0.35 & 0.24 & $1.81 *$ \\
\hline \multirow{8}{*}{10} & \multirow{4}{*}{4} & 0.6 & 43.45 & 0.32 & \multirow{2}{*}{0.27} & 0.84 \\
\hline & & 0.7 & 42.73 & 034 & & 0.95 \\
\hline & & 0.8 & 42.70 & & 0.30 & 0.99 \\
\hline & & 0.9 & 44.50 & 0.44 & 0.26 & 1.20 \\
\hline & \multirow{4}{*}{6} & 0.6 & 37.50 & 0.30 & 0.29 & 0.98 \\
\hline & & 0.7 & 37.80 & 0.33 & 0.32 & 1.10 \\
\hline & & 0.8 & 38.00 & 0.35 & 0.28 & 1.25 \\
\hline & & 0.9 & 38.04 & 0.38 & 0.30 & 1.35 \\
\hline
\end{tabular}


Continuation Table 4

\begin{tabular}{c|c|c|c|c|c|c}
\hline 1 & 2 & 3 & 4 & 5 & 6 & 7 \\
\hline \multirow{3}{*}{10} & & 0.6 & 28.16 & 0.34 & 0.28 & 0.85 \\
& \multirow{3}{*}{8} & 0.7 & 28.20 & 0.31 & 0.35 & 0.98 \\
& & 0.8 & 29.20 & 0.38 & 0.62 & $0.8^{*}$ \\
& & 0.9 & 31.10 & 0.37 & - & $0.4 *$
\end{tabular}

N o t e : The destruction occurred during cyclic loading.

The zone of influence of a weak layer on the strength and deformability of foundation is limited to the depth $h_{s}=D_{s t}$. The location of the layer in the zone below the diameter of the model has virtually no effect on the bearing capacity of the foundation. The application of reinforcement excluded the possibility of landslide slope collapse. The destruction occurred only in the form of punching of soil bulk with the formation of cracks on both the horizontal and sloping surfaces. With each cycle, the subsidence increased at the rate dependent on the rate of loading.

\section{References}

1. Lomtadze V.D. Inzhenernaya geologiya. Spetsial'naya inzhenernaya geologiya [Engineering geology. Special Engineering Geology], Leningrad: Nedra, 1978, 496 p. (In Russ.)

2. Dzhouns K.D., Mel'nika V.G. Sooruzheniya iz armirovannogo grunta [Constructions of reinforced soil], Moscow: Stroiizdat, 1989, 280 p. (In Russ.)

3. Shapiro D.M. Teoriya i raschetnye modeli osnovanii $i$ ob"ektov geotekhniki : monografiya [Theory and computational models of bases and facilities Geotechnicks: monograph], Voronezh: Nauchnaya kniga, 2012, 164 p. (In Russ.)

4. Yakovlev P.I. Ustoichivost' transportnykh gidrotekhnicheskikh sooruzhenii : monografiya [Sustainable transport waterworks: monograph], Moscow:Transport, 1986, 191 p. (In Russ.)

5. Dobrov E.M. Mekhanika gruntov : uchebnik dlya vuzov po spetsial'nostyam napravleniya "Transportnoe stroitel'stvo" [Soil Mechanics: a textbook for high schools in the field direction "Transport construction"], Moscow: Akademiya, 2008, 272 p. (In Russ.)

6. Semendyaev L.I. [Optimized calculation of reinforced slope in a mustacheditions of individual design], Avtomobil'nye dorogi: Inform. sb./ Informavtodor [Highways: Inform. Sat / Informavtodor], 1998, ussue 10, pp. 8-20. (In Russ.)

7. Antonov V.M., Ledenev V.V. [Experimental study of reinforced foundations], Vestnik tsentral'nogo regional'nogo otdeleniya Rossiiskoi akademii arkhitektury $i$ stroitel'nykh nauk [Bulletin of the Central Regional Branch of the Russian Academy of Architecture and Construction Sciences], 2007, no. 6, pp. 3-11. (In Russ.)

8. Antonov V.M. Eksperimental'nye issledovaniya armirovannykh osno-vanii : monografiya [Experimental study of reinforced Ba-ments: a monograph], Tambov: Izd-vo GOU VPO “TGTU”, 2011, 80 p. (In Russ.)

\section{Список литературь}

1. Ломтадзе, В. Д. Инженерная геология. Специальная инженерная геология / В. Д. Ломтадзе. - Л. : Недра, 1978. - 496 с. 
2. Джоунс, К. Д. Сооружения из армированного грунта / К. Д. Джоунс. - Пер. с англ. В. С. Забавина ; под ред. В. Г. Мельника. - М. : Стройиздат, 1989. - 280 с.

3. Шапиро, Д. М. Теория и расчетные модели оснований и объектов геотехники : монография / Д. М. Шапиро. - Воронеж : Научная книга, 2012. - 164 с.

4. Яковлев, П. И. Устойчивость транспортных гидротехнических сооружений : монография / П. И. Яковлев. - М. :Транспорт, 1986. - 191 с.

5. Добров, Э. М. Механика грунтов : учеб. для вузов по специальностям направления «Транспортное строительство» / Э. М. Добров. - М. : Академия, 2008. $272 \mathrm{c}$.

6. Семендяев, Л. И. Оптимизированный расчет армированных откосов в условиях индивидуального проектирования / Л. И. Семендяев // Автомобильные дороги. - 1998. - Вып. 10. - С. 8 - 20.

7. Антонов, В. М. Экспериментальные исследования армированных оснований / В. М. Антонов, В.В.Леденев // Вестн. центр. регион. отд-ния Росс. акад. архитектуры и строит. наук. - 2007. - № 6. - С. 3 - 11 .

8. Антонов, В. М. Экспериментальные исследования армированных оснований : монография / В. М. Антонов. - Тамбов : Изд-во ГОУ ВПО «ТГТУ», 2011. $-80 \mathrm{c}$.

\section{Экспериментальные исследования устойчивости армированных песчаных откосов}

\section{В. М. Антонов, М. В. Антонов, О. В. Евдокимцев, В. В. Леденев}

ФГБОУ ВО «Тамбовский государственный технический университет», г. Тамбов, Россия

Ключевые слова: армирование; деформации; нагрузка циклическая; откос; разрушающая нагрузка.

Аннотация: Приведены результаты экспериментальных исследований устойчивости армированного песчаного откоса при действии вертикальной пригрузки. Проведено несколько серий опытов, в которых изменялась глубина заложения армирующего элемента и параметры повторного нагружения - циклический $(5,10$ и 20 циклов нагружения) и статический. Рассмотрен случай наличия прослойки слабого грунта, расположенной на различной глубине в пределах откоса.

Представлены зависимости влияющих параметров на перемещения и предельные давления под подошвой экспериментального штампа. Показано, что откос армированный сеткой может нести вертикальную нагрузку почти в 2 раза больше, чем неармированный, при меньших деформациях. Абсолютные значения разрушающей нагрузки после циклирования больше, чем при статических нагрузках. Выявлено, что применение армирования исключает возможность оползневого обрушения откоса, а расположение прослойки слабого грунта на глубине, превышающей диаметр модели, не влияет на несущую способность откоса и делает армирование в данной зоне неэффективным.

(C) B. М. Антонов, М. В. Антонов, О. В. Евдокимцев, В. В. Леденев, 2016 